\title{
7.3. ПОВЫШЕНИЕ ЭФФЕКТИВНОСТИ СТОИМОСТНЫХ МЕТОДОВ УПРАВЛЕНИЯ ФИНАНСАМИ КОРПОРАЦИИ
}

\author{
Федотова М.Ю., к.э.н., доцент кафедры «Финансы»; \\ Тагирова О.А., к.э.н., доцент кафедры «Финансы»; \\ Носов А.В., к.э.н., доцент кафедры «Финансы»; \\ Мурзин Д.А., к.э.н., доцент кафедры «Финансы».
}

\section{ФГБОУ ВО Пензенский государственный аграрный университет, г. Пенза}

В статье в качестве критерия оценки развития компании предложено использование ее стоимости. Расчеты с помощью метода чистых активов показали, что за последние пять лет стоимость исследуемой организации значительно снизилась, это свидетельствует о недостаточной эффективности управления фринансами. Проведен анализ фракторов, влияющих на стоимость компании, и сделан вывод о верной стратегии ее развития. Росту стоимости может помочь выпуск новой продукции и закупка нового оборудования, структурная перестройка, повышение прозрачности и открытости бизнеса. Предложена система управления стоимостью компании и выделены факторы ее успешного внедрения.

\section{Литература}

1. Галиахметов Р.А. Развитие концепции управления стоимостью предприятия и ее роль в современной экономической системе [Текст] / Р.А. Галиахметов // Вестн. Ижевского гос. техн. унт-та. - 2017. - №4. - С. 13-18.

2. Домнина С.В. Модель управления стоимостью бизнеса [Текст] / С.В. Домнина, Е.В. Савоскина // Вестн. Самарского гос. ун-та. - 2015. - №8. - С. 1823.

3. Коупленд Т. и др. Стоимость компаний: оценка и управление [Текст] / Т. Коупленд, Т. Коллер, Дж. Муррин. - М. : Олимп-бизнес, 2005. - 576 с.

4. Кривец В.В. Методы определения стоимости бизнеса, основанные на оценке активов предприятий [Текст] : учеб. пособие / В.В. Кривец. - М. : Финансы и статистика, 2017. - 73 с.

5. Любимова М.В. Оценка и управление стоимостью бизнеса [Текст] / М.В. Любимова, В.К. Федорова // Вестн. Ин-та экон. и упр. Новгородского гос. ун-та им. Ярослава Мудрого. - 2017. - №1. - С. 41-45.

6. Особенности оценки стоимости бизнеса в различных сферах экономики [Текст] : монография / А.В. Носов, О.А. Тагирова, М.Ю. Федотова и др. - Пенза : РИО ПГАУ, 2019. - 282 с.

7. Романенко О.А. Увеличение стоимости компании как стратегическая цель и критерий оценки управленческих решений [Текст] / О.А. Романенко // Наука и общество. - 2016. - №3. - С. 103-108.

8. Сутягин В.Ю. Факторы и проблема роста стоимости российских компаний [Текст] / В.Ю. Сутягин, О.М. Шепелев // Социально-экономические явления и процессы. - 2015. - №1. - С. 104-112.

9. Тагирова О.А. Управление стоимостью организации на основе оценки [Текст] / О.А. Тагирова, О.В. Новичкова // К 65летию ФГБОУ ВО Пензенская ГСХА : сб. науч. тр. профессорско-преподавательского состава / МНИЦ ПГСХА. - Пенза : РИО ПГСХА, 2017. - С. 270-271.

10. Федотова М.Ю. Методы стоимостной оценки эфффективности управления компанией [Текст] / М.Ю. Федотова, С.Д. Ляхова // Управление реформированием социально-экономического развития предприятий, отраслей, регионов : сб. науч. ст. V Междунар. науч.-практ. конф. студентов, аспирантов и преподавателей. - Пенза : Изд-во ПГУ, 2015. C. 44-49.

11. Федотова М.Ю. и др. Особенности оценки рыночной стоимости коммерческого банка [Текст] / М.Ю. Федотова, А.В. Носов, О.А. Тагирова и др. // Нива Поволжья. - 2017. - №2. - С. 125-133.

12. Федотова М.Ю. Оценка стоимости бизнеса и использование ее результатов в целях повышения эффективности деятельности компании [Текст] / М.Ю. Федотова // Финансовый менеджмент. - 2009. - №5. - С. 3-22.

13. Федотова М.Ю. Управление стоимостью бизнеса закрытых компаний [Текст] / М.Ю. Федотова // Актуальные проблемы финансирования и налогообложения АПК в условиях глобализации экономики : сб. ст. IV Всеросс. науч.-практ. конф. / МНИЦ ПГАУ. - Пенза : РИО ПГАУ, 2018. - С. 159-163.

14. Федотова М.Ю. Управление финансами корпорации на основе концепции стоимости [Текст] / М.Ю. Федотова // Бухгалтерский учет, анализ, аудит и налогообложение: проблемы и перспективы : сб. ст. VII Всеросс. науч.-практ. конф. / МНИЦ ПГАУ. - Пенза : РИО ПГАУ, 2019. - С. 177-181.

15. Шихвердиев А.П. и др. Управление рыночной стоимостью компаний в концепции устойчивого развития [Текст] / А.П. Шихвердиев, С.Н. Большаков, Е.А. Рауш // Вестн. Науч.-иссл. центра корпоративного права, управления и венчурного инвестирования Сыктывкарского гос. ун-та. - 2016. - №1. - С. 97-115.

16. ШохазамийШ.Ш. Стоимостная концепция финансового управления компанией [Текст] / Ш.Ш. Шохазамий, Р.Р. Абдураупов // Проблемы современной экономики. - 2016. - №1. - С. 143-148.

\section{Ключевые слова}

Стоимость предприятия; эффрективность; управление финансами; затратный подход; метод чистых активов; фракторы; прибыль; стратегия; структурная перестройка; концепция управления стоимостью. 
Носов Алексей Викторович

Мурзин Денис Александрович

\section{РЕЦЕНЗИЯ}

Актуальность. Актуальность темы исследования обусловлена тем, что при принятии любого управленческого решения необходимо оценивать его влияние на стоимость компании, на ее ликвидность и другие финансовые показатели. Концепция управления на основе стоимости - это динамично развивающееся направление стратегического и финансового менеджмента. Процесс оценки бизнеса является основанием для выработки финансово-экономической стратегии. Вложение средств в компанию окажется максимально выгодным лишь в том случае, если фринансовые менеджеры будут объективно оценивать стоимость вверенного им бизнеса и делать все, чтобы она непрерывно росла. Результаты оценки бизнеса, получаемые на основе анализа внешней и внутренней информации, необходимы не только для проведения переговоров о купле-продаже - они играют существенную роль при выборе стратегии развития предприятия: в процессе стратегического планирования важно оценить будущие доходы предприятия, степень его устойчивости и ценность имиджа; для принятия обоснованных управленческих решений необходима инфляционная корректировка данных финансовой отчетности, являющейся базой для принятия финансовых решений; для обоснования инвестиционных проектов по приобретению и развитию бизнеса нужно иметь сведения о стоимости всего предприятия или части его активов. Повышение стоимости предприятия - один из показателей роста доходов его собственников. В связи с этим периодическое проведение оценки стоимости бизнеса можно использовать для анализа эффективности управления финансами предприятия.

Научная новизна и практическая значимость. В рецензируемой статье на примере конкретной компании осуществлен расчет ее стоимости методом чистых активов и выявлено, что за последние пять лет она снизилась. На основе этого сделан вывод о недостаточной эффективности управления финансами компании. Данное предприятие достаточно успешно справляется с улучшением показателей прибыли в ущерб долгосрочной рыночной позиции. Так как такая ориентация деятельности недальновидна, руководству организации рекомендовано принять решение о внедрении у себя системы управления стоимостью, и в качестве основного показателя эффективности деятельности предприятия принять стоимость компании. Кроме этого, выявлены факторы успешного внедрения системы управления стоимостью, на которые следует влиять.

Заключение: рецензируемая статья отвечает требованиям, предъявляемым к научным публикациям, и может быть рекомендована к опубликованию.

Бондин И. А., д.э.н., профрессор, декан Экономического ффакультета ФГБОУ ВО «Пензенский государственный аграрный университет», г. Пенза.

DOI 10.38097/AFA.2020.50.89.023 